\title{
INVESTIGATION OF CONCRETE-FILLED STEEL COMPOSITE (CFSC) STUB COLUMNS WITH BAR STIFFENERS
}

\author{
Alireza BAHRAMI, Wan Hamidon WAN BADARUZZAMAN, Siti Aminah OSMAN \\ Department of Civil and Structural Engineering, Universiti Kebangsaan Malaysia, Bangi, Selangor, \\ Malaysia
}

Received 1 Aug. 2011; accepted 19 Oct. 2011

\begin{abstract}
This paper is concerned with the investigation of concrete-filled steel composite (CFSC) stub columns with bar stiffeners. In order to study the behaviour of the columns, the finite element software LUSAS is used to conduct the non-linear analyses. Results from the non-linear finite element analysis and the corresponding experimental test are compared which reveal the reasonable accuracy of the three-dimensional finite element modelling. A special arrangement of bar stiffeners in the columns with various number, spacing and diameters of the bar stiffeners are developed and studied using the non-linear finite element method. Effects of various variables such as different number and spacing of the bar stiffeners and also steel wall thicknesses on the ultimate axial load capacity and ductility of the columns are examined. Moreover, effects of different diameters of the bar stiffeners, concrete compressive strengths and steel yield stresses on the ultimate axial load capacity of the columns are evaluated. It is concluded from the study that the variables significantly influence the behaviour of the columns. The obtained results from the finite element analyses are compared with those predicted values by the design code EC4 and suggested equations of the previous researches.
\end{abstract}

Keywords: composite stub column; bar stiffener; non-linear finite element; steel wall; concrete compressive strength; steel yield stress; ultimate axial load capacity; ductility.

Reference to this paper should be made as follows: Bahrami, A.; Wan Badaruzzaman, W. H.; Osman, S. A. 2013. Investigation of concrete-filled steel composite (CFSC) stub columns with bar stiffeners, Journal of Civil Engineering and Management 19(3): 433-446.

\section{Introduction}

Steel columns have the benefits of high ductility and tensile strength; on the other hand, reinforced concrete columns possess the benefits of large stiffness and compressive strength. Composite columns which comprise steel and concrete also have the structural advantages of the two materials. Concrete-filled steel composite (CFSC) columns are an alternative to steel and reinforced concrete columns in modern civil projects worldwide. The steel consumption in the CFSC columns is less than the steel columns which leads to cost saving. Also, the CFSC columns not only have structural benefits such as high strength, large stiffness and high ductility but also possess ecological benefits over reinforced concrete columns: reinforcement and formwork are not utilised in the CFSC columns which result in a clean construction site; when the building is demolished, high-strength concrete which is without reinforcement in the CFSC columns can be easily crushed and reused as aggregates. Also, the steel wall which peels from the concrete core can be used again. A number of theoretical and experimental research works have been done during the past years on the CFSC columns. Shakir-Khalil and Mouli (1990) tested nine $3 \mathrm{~m}$ long composite columns of concrete-filled rectangular hollow sections and studied experimentally 12 short specimens under axial compression to establish the squash load of the stub columns. Effects of different materials and geometric properties on the strength and ductility of concrete-filled steel box columns were investigated by Uy (1998). Lakshmi and Shanmugam (2002) presented a semi-analytical method to predict the behaviour of in-filled steelconcrete composite columns. Twelve high-strength rectangular concrete-filled steel hollow section columns were tested under pure bending by Gho and Liu (2004). Liu (2005) evaluated experimentally 22 highstrength rectangular concrete-filled steel hollow section columns in order to investigate three parameters including material strength, cross sectional aspect 
ratio and volumetric steel-to-concrete ratio. Tests on concrete-filled steel tubular stub columns with inner and outer welded longitudinal stiffeners were reported by Tao et al. (2005) under axial compression. Guo et al. (2007) conducted tests on 24 bare steel and concrete-filled tubes to study the occurrence of local buckling. Reasons of the complex stress state appearance and behaviour of hollow concrete-filled steel tubular element components in various load stages of compressed stub structural member were analysed by Kuranovas and Kvedaras (2007). Han et al. (2008) performed 46 tests on thin-walled steel tube confined concrete stub columns subjected to axial compression to assess effects of sectional type, local compression area ratio and steel tube width-to-wall thickness ratio on the behaviour of the columns. Experimental investigation of stiffened thin-walled hollow steel structural stub columns filled with concrete was carried out by Tao et al. (2008) to uncover strength and ductility of such columns. Load carrying capacity of thin-walled box-section stub columns fabricated by high-strength steel was experimentally evaluated by Gao et al. (2009) under uniaxial compression. Several types of concrete-filled steel columns were tested by Kuranovas et al. (2009) to determine their loadcarrying capacities. Petrus et al. (2010) presented effects of tab stiffeners on the bond and compressive strengths of concrete-filled thin-walled steel tubes. Goode et al. (2010) analysed the experimental data of concrete-filled steel tubes. Circular and rectangular hollow section stub and long columns fully with concrete were investigated with and without applied moments at the ends of the specimen. de Oliveira et al. (2010) assessed experimentally passive confinement effect of the steel tube in concrete-filled steel tubular columns. A series of tests were performed on short and slender concrete-filled stainless steel tubular columns by Uy et al. (2011) to illustrate their performance under axial compression and combined action of axial force and bending moment. Twenty-eight concretefilled steel tubular stub columns subjected to eccentric partial compression were tested by Yang and Han (2011) to study effects of parameters such as section type, load eccentricity ratio and shape of the loading bearing plate. Bahrami et al. (2011a) studied structural behaviour of CFSC slender columns to investigate and develop different shapes (V, T, L, Line \& Triangular) and number ( 1 on side \& 2 on side) of longitudinal cold-formed steel sheeting stiffeners and also evaluate their effects on the behaviour of the columns. However, it seems that limited researches have been conducted on the behaviour of the CFSC stub columns with bar stiffeners.

This paper presents the investigation of the CFSC stub columns with bar stiffeners. To establish the accuracy of the modelling in this study, the experimental test result reported by Tao et al. (2005) is used to compare with the proposed three-dimensional (3D) finite element modelling. A special arrangement of bar stiffeners in the columns with various number, spacing and diameters of the bar stiffeners are developed using the non-linear finite element method. The investigation of the CFSC stub columns is further carried out by considering different variables in the non-linear finite element analyses. The main variables are such as number of bar stiffeners (2, 3 and 4), spacing of bar stiffeners (from 50 to $150 \mathrm{~mm}$ ), diameter of bar stiffeners (from 8 to $12 \mathrm{~mm}$ ), steel wall thicknesses (from 2 to $3 \mathrm{~mm}$ ), concrete compressive strengths (from 30 to $50.1 \mathrm{MPa}$ ) and steel yield stresses (from 234.3 to $450 \mathrm{MPa})$. Effects of various number and spacing of the bar stiffeners and also steel wall thicknesses on the ultimate axial load capacity and ductility of the columns are evaluated. Also, effects of different diameters of the bar stiffeners, concrete compressive strengths and steel yield stresses on the ultimate axial load capacity of the columns are assessed. The obtained ultimate axial load capacities from the non-linear finite element analyses are compared with the predicted capacities by the design code Eurocode 4 (2004) and recommended equations by Baig et al. (2006) and Bahrami et al. (2011b).

\section{Description of non-linear finite element modelling}

The experimental test of a CFSC stub column performed by Tao et al. (2005) has been chosen for the non-linear modelling using the finite element software LUSAS herein. Figure 1 shows the cross section and elevation of the column. The steel wall thickness of the column was $2.5 \mathrm{~mm}$. In the experimental test, concrete was vertically poured in the steel box in layers. Each layer was vibrated using a poker vibrator. The column was then located upright to air until testing. The environmental average temperature and relative humidity were about $15{ }^{\circ} \mathrm{C}$ and $80 \%$, respectively. The column was tested to failure under axial compression using a $5000 \mathrm{kN}$ capacity testing machine after 28 days of curing in the laboratory. The

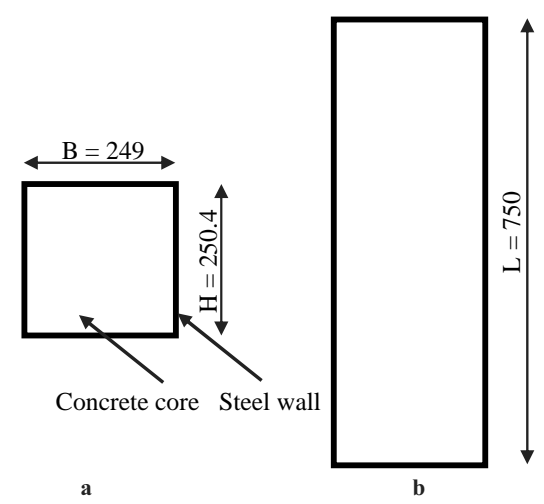

Fig. 1. Unstiffened CFSC stub column: (a) cross section; (b) elevation, (unit: $\mathrm{mm}$ ) 
test of the column was conducted with a loading rate of $0.2 \mathrm{~mm} / \mathrm{min}$ before the ultimate load capacity was reached. The loading rate was thereafter changed to $0.5 \mathrm{~mm} / \mathrm{min}$.

\subsection{Material properties and constitutive models}

The steel wall, steel bar stiffener and concrete are the materials used in the numerical analysis of this study. The material properties and their constitutive models are presented as follows.

\subsubsection{Steel wall}

The steel wall has been modelled as an elasticperfectly plastic material in both tension and compression. Figure 2 illustrates the stress-strain curve used for the steel wall. The yield stress, modulus of elasticity and Poisson's ratio of the steel wall have been adopted identical to those of the corresponding experimental test done by Tao et al. (2005), respectively as $234.3 \mathrm{MPa}, 208,000 \mathrm{MPa}$ and 0.247. Von Mises yield criterion, an associated flow rule, and isotropic hardening have been employed in the nonlinear material model.

\subsubsection{Steel bar stiffener}

The uniaxial behaviour of the steel bar stiffener is similar to that of the steel wall. Accordingly, it can be simulated by the elastic-perfectly plastic material model (Fig. 2). The yield stress and modulus of

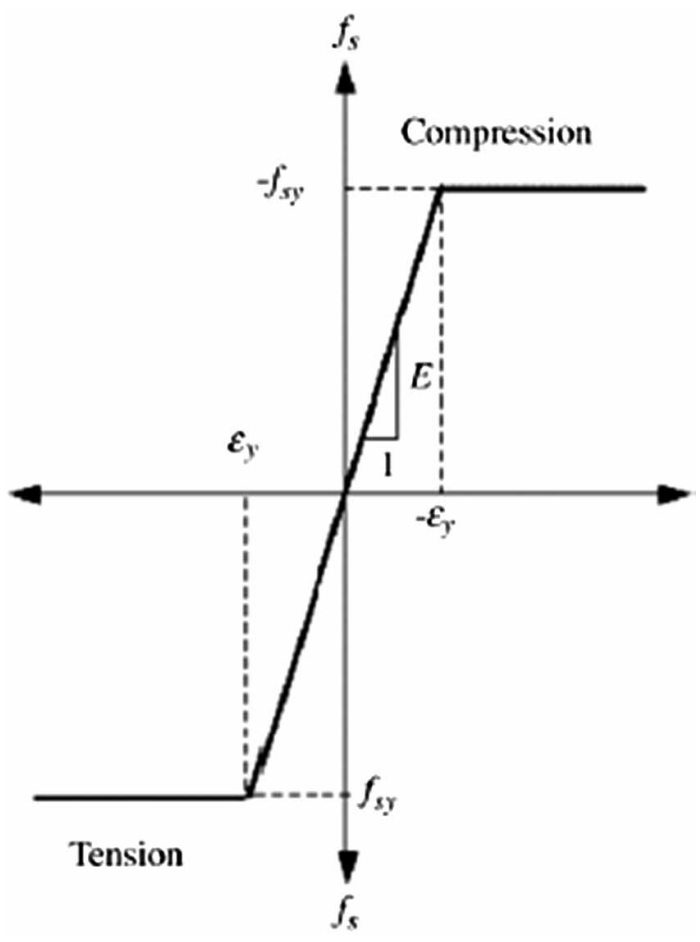

Fig. 2. Stress-strain curve for steel elasticity of the steel bar stiffener have been taken as $400 \mathrm{MPa}$ and 200,000 MPa, respectively.

\subsubsection{Concrete}

The compressive strength and modulus of elasticity of concrete have been taken identical to those of the corresponding experimental test done by Tao et al. (2005), respectively as $50.1 \mathrm{MPa}$ and $35,100 \mathrm{MPa}$. Figure 3 indicates the equivalent uniaxial stress-strain curves utilised for concrete (Ellobody, Young 2006a, b). The unconfined concrete cylinder compressive strength $f_{c}$ is equal to $0.8 f_{c u}$ in which $f_{c u}$ is the unconfined concrete cube compressive strength. The corresponding unconfined strain $\varepsilon_{c}$ is usually around the range of $0.002-0.003$, as recommended by $\mathrm{Hu}$ et al. (2005). The $\varepsilon_{c}$ was considered as 0.002 in their study. The same value for $\varepsilon_{c}$ has been also adopted in the analyses of this study. When concrete is under laterally confining pressure, the confined compressive strength $f_{c c}$ and the corresponding confined strain $\varepsilon_{c c}$ are much higher than those of unconfined concrete.

Eqns (1) and (2) have been respectively used to determine the confined concrete compressive strength $f_{c c}$ and the corresponding confined stain $\varepsilon_{c c}$ (Mander et al. 1988):

$$
\begin{gathered}
f_{c c}=f_{c}+k_{1} f_{1} ; \\
\varepsilon_{c c}=\varepsilon_{c}\left(1+k_{2} \frac{f_{1}}{f_{c}}\right),
\end{gathered}
$$

where: $f_{1}$ is the lateral confining pressure provided by the steel wall for the concrete core. The approximate value of $f_{1}$ can be obtained from the interpolation of the values presented by Hu et al. (2003). The factors of $k_{1}$ and $k_{2}$ have been considered as 4.1 and 20.5, respectively (Richart et al. 1928). Because $f_{1}, k_{1}$ and $k_{2}$ are known $f_{c c}$ and $\varepsilon_{c c}$ can be determined using Eqns (1) and (2).

The equivalent uniaxial stress-strain curve for confined concrete (Fig. 3) is consisted of three parts which should be defined. The first part comprises the

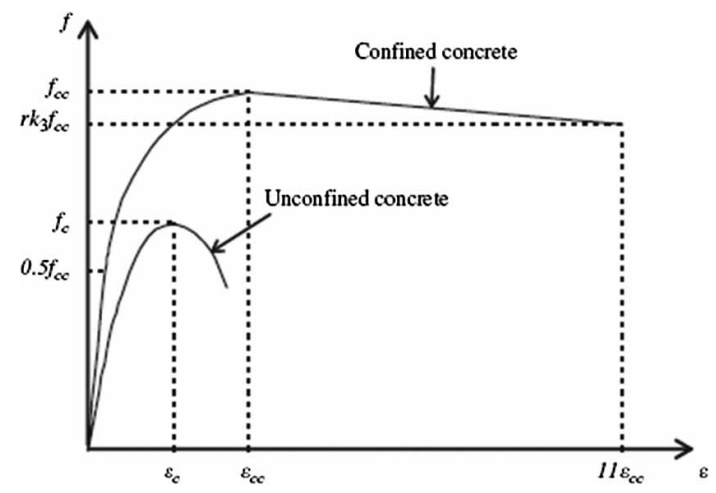

Fig. 3. Equivalent uniaxial stress-strain curves for concrete (Ellobody, Young 2006b) 
initially assumed elastic range to the proportional limit stress. The value of the proportional limit stress has been considered as $0.5 f_{c c}$ ( $\mathrm{Hu}$ et al. 2003). The empirical Eqn (3) has been used to obtain the initial Young's modulus of confined concrete $E_{c c}$ (ACI 31899 1999). The Poisson's ratio $v_{c c}$ of confined concrete has been chosen as 0.2 :

$$
E_{c c}=4700 \sqrt{f_{c c}} \mathrm{MPa} .
$$

The second part is the non-linear portion which starts from the proportional limit stress $0.5 f_{c c}$ to the confined concrete strength $f_{c c}$. The common Eqn (4) can be used to obtain this part (Saenz 1964). The values of uniaxial stress $f$ and strain $\varepsilon$ are the unknowns of the equation that define this part of the curve. The strain value $\varepsilon$ has been adopted between the proportional strain $\left(0.5 f_{c c} / E_{c c}\right)$, and the confined strain $\varepsilon_{\mathrm{cc}}$ which corresponds to the confined concrete strength. By assuming the strain values $\varepsilon$, Eqn (4) can be used to calculate the stress values $f$ :

$$
f=\frac{E_{c c} \varepsilon}{1+\left(R+R_{E}-2\right)\left(\frac{\varepsilon}{\varepsilon_{c c}}\right)-(2 R-1)\left(\frac{\varepsilon}{\varepsilon_{c c}}\right)^{2}+R\left(\frac{\varepsilon}{\varepsilon_{c c}}\right)^{3}},
$$

where:

$$
\begin{gathered}
R_{E}=\frac{E_{c c} \varepsilon_{c c}}{f_{c c}} ; \\
R=\frac{R_{E}\left(R_{\sigma}-1\right)}{\left(R_{\varepsilon}-1\right)^{2}}-\frac{1}{R_{\varepsilon}} .
\end{gathered}
$$

The constants $R_{\varepsilon}$ and $R_{\sigma}$ have been considered as 4 in this study (Hu, Schnobrich 1989). The third part of the curve consists of the descending part that is between $f_{c c}$ and $r k_{3} f_{c c}$ with the corresponding strain of $11 \varepsilon_{c c}$. The reduction factor $k_{3}$ depends on the $H / t$ ratio and the steel wall yield stress $f_{y}$. Empirical equations given by $\mathrm{Hu}$ et al. (2003) can be used to determine the approximate value of $k_{3}$. To take into account the effect of different concrete strengths, the reduction factor $r$ was introduced by Ellobody et al. (2006) on the basis of the experimental study performed by Giakoumelis and Lam (2004). The value of $r$ has been considered as 1.0 for concrete with cube strength $f_{c u}$ of $30 \mathrm{MPa}$ and as 0.5 for concrete with $f_{c u}$ greater than or equal to $100 \mathrm{MPa}$ (Mursi, Uy 2003). The value of $r$ for concrete cube strength between 30 and $100 \mathrm{MPa}$ has been interpolated in this study. A linear Drucker-Prager yield criterion $G$ (Fig. 4) has been used to model the yielding part of the curve which is the part after the proportional limit stress (Ellobody, Young 2006a, b; Hu et al. 2005). This criterion has been utilised to define yield surface and flow potential parameters for concrete under triaxial compressive stresses. Also, this criterion has been used

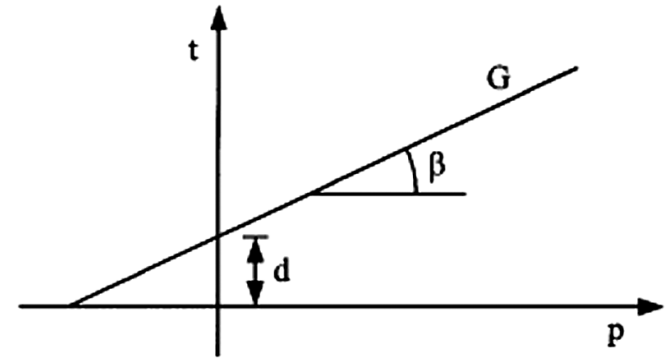

Fig. 4. Linear Drucker-Prager yield criterion for concrete (Hu et al. 2005)

with associated flow and isotropic rule. The criterion is expressed as Eqn (7):

$$
G=t-p \tan \beta-d=0,
$$

in which $t, p$ and $d$ are obtained from the following equations:

$$
\begin{aligned}
t & =\frac{\sqrt{3 J_{2}}}{2}\left[1+\frac{1}{k}-\left(1-\frac{1}{k}\right)\left(\frac{r}{\sqrt{3 J_{2}}}\right)^{3}\right] \\
r & =\left[\frac{9}{2}\left(S_{1}^{3}+S_{2}^{3}+S_{3}^{3}\right)\right]^{1 / 3} ; \\
p & =\frac{-\left(\sigma_{1}+\sigma_{2}+\sigma_{3}\right)}{3} ; \\
d & =\left(1-\frac{\tan \beta}{3}\right) f_{c c}^{\prime} .
\end{aligned}
$$

$S_{1}, S_{2}$ and $S_{3}$ are principal stress deviators, $\sigma_{1}, \sigma_{2}$ and $\sigma_{3}$ are the principle stresses and $J_{2}$ is the second stress invariant of the stress deviator tensor. The ratio of flow stress in triaxial tension to that in compression $K$ and the material angle of friction $\beta$ have been chosen as 0.8 and $20^{\circ}$, respectively (Hu et al. 2003).

\subsection{Finite element type and mesh}

Element types for the steel wall and concrete core of the columns were chosen from the element library of the finite element software LUSAS (2006) in this study. The 6-noded triangular shell element, TSL6, was utilised to model the steel wall. This is a thin, doubly-curved, isoparametric element that can be used to model 3D structures. It has six degrees of freedom per node and provides accurate solution to most applications. This element can accommodate generally curved geometry with varying thickness and anisotropic and composite material properties. The element formulation considers both membrane and flexural deformations. The steel bar stiffeners were modelled by the 3-noded bar element type BRS3. This is an isoparametric bar element in $3 \mathrm{D}$ which can accommodate varying cross sectional area. This element is suitable to model stiffening reinforcement with continuum elements. The 10-noded tetrahedral ele- 
ment, TH10, was used for modelling of the concrete core. This element is a 3D isoparametric solid continuum element capable of modelling curved boundaries. This is a standard volume element of the LUSAS software (2006). The elements can be employed for linear and complex non-linear analyses involving contact, plasticity and large deformations.

Different finite element mesh sizes were examined to find a reasonable mesh size which can achieve accurate results. As a result, the mesh size corresponding to 7713 elements was revealed to obtain exact results. A typical finite element mesh used in this study is illustrated in Figure 5.

\subsection{Boundary conditions and load application}

The pin-pin boundary conditions have been considered in the 3D finite element modelling in this study. Therefore, the rotations of the top and bottom surfaces of the columns in the $\mathrm{X}, \mathrm{Y}$ and $\mathrm{Z}$ directions were considered to be free. Also, the displacements of the bottom and top surfaces in the $\mathrm{X}$ and $\mathrm{Z}$ directions were restrained. On the other hand, the displacement

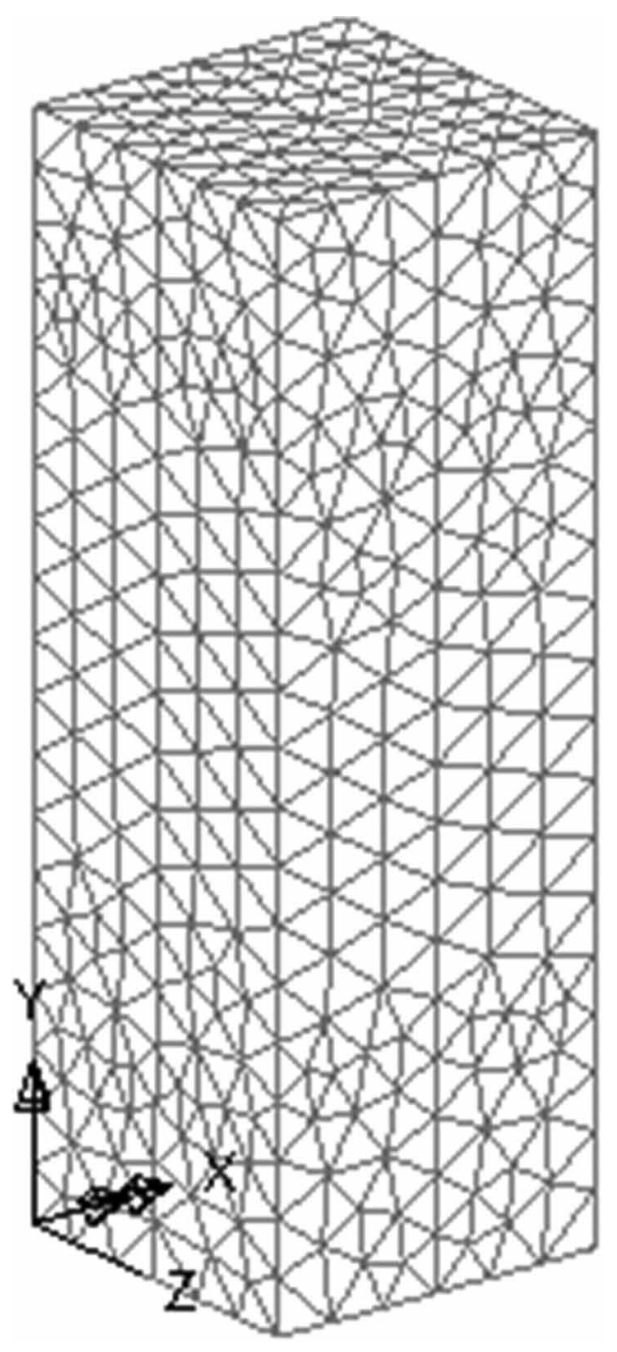

Fig. 5. Typical finite element mesh used in this study of the bottom surface in the $\mathrm{Y}$ direction was restrained while that of the top surface, in the direction of the applied load and where the load is applied, was set to be free.

The load application on the column in the modelling was on the basis of the loading arrangement in the corresponding experimental test of the column. The axial load of the experimental test was exactly modelled by incremental displacement load with an initial increment of $1 \mathrm{~mm}$ in the negative $\mathrm{Y}$ direction acting axially to the top surface of the column. Increment is a step in a non-linear analysis where a portion of the total load is applied. The increment change was $0.1 \mathrm{~mm}$ in the analysis. Iteration is a step within a load increment where the analysis solver attempts to converge to an acceptable solution. The iterations per increment were 10 in the analysis. Incremental loading adds displacements to a previous increment (LUSAS 2006). Each step in the non-linear analysis was a small amount of the displacement of the column and it was continued up to the failure of the column.

\subsection{Modelling of concrete-steel interface}

The contact between the concrete core and the steel wall was simulated by slide-lines. The slide-lines attributes can be used to model contact surfaces in the finite element software LUSAS (2006). The slideline contact facility is non-linear. Slave and master surfaces should be selected correctly to provide the contact between two surfaces, steel and concrete. If a smaller surface is in contact with a larger surface, the smaller surface can be best selected as the slave surface. If it is not possible to distinguish this point, the body which has higher stiffness should be selected as the master surface. It needs to be mentioned that the stiffness of the structure should be taken into account and not just the material. Although, the steel material is stiffer than the concrete material, the steel wall may have less stiffness than the volume of the concrete core in this study. Consequently, the concrete core and steel wall surfaces were respectively selected as the master and slave surfaces. Dabaon et al. (2009) has also presented this process of choosing master and slave surfaces. The slide-lines have the capability of defining properties such as friction coefficient. The friction between two surfaces, the steel wall and concrete core, is considered so that they can remain in contact. The Coulomb friction coefficient in slidelines was selected as 0.25 . The slide-lines allow the concrete core and steel wall to separate or slide but not to penetrate each other.

\subsection{Accuracy of modelling}

The finite element modelling result was compared with the experimental test result reported by Tao et al. 


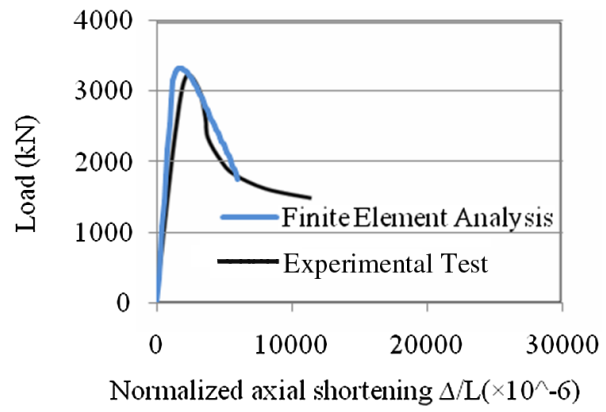

Fig. 6. Load versus normalised axial shortening curves for the stub columns

(2005) to reveal the accuracy of the 3D modelling in this study. According to Figure 6, the curves obtained from the modelling and corresponding experimental test agree well with each other. The difference between the ultimate axial load capacity obtained from the modelling $3325 \mathrm{kN}$, and that from the experimental test $3230 \mathrm{kN}$ is only $2.9 \%$. This small difference demonstrates the accuracy of the finite element modelling. As a result, the accurate prediction of the behaviour of the columns is absolutely possible by the proposed 3D finite element modelling in this study.

\section{Numerical analysis}

Since the proposed 3D finite element modelling of this study was demonstrated to be accurate, the method was utilised for the non-linear analysis of stub columns of same size and cross section as that of Tao et al. (2005) but with bar stiffeners. The previously explained modelling specifications were exactly employed for simulating each of the CFSC stub columns. Details of the stiffened CFSC stub columns which were analysed by the use of the non-linear finite element method are illustrated in Figure 7. Figure 7a indicates the arrangement of the bar stiffeners in the columns. Different number (2,3 and 4) and spacing of the bar

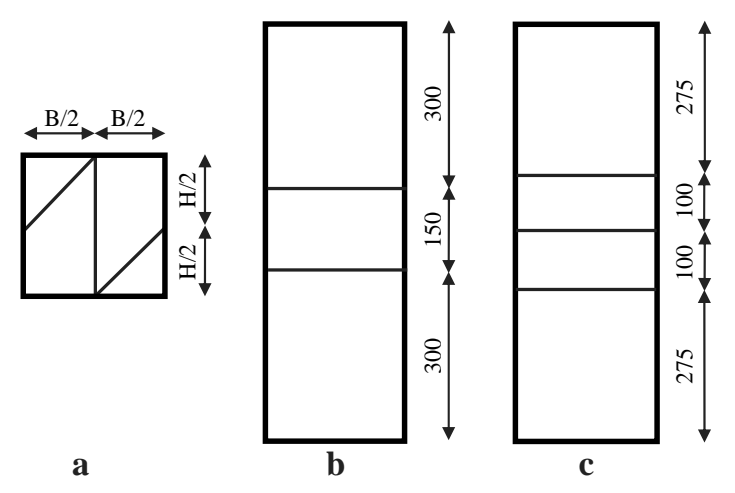

Fig. 7. Details of the stiffened CFSC stub columns: (a) arrangement of bar stiffeners in the column; (b) typical elevation of column with 2 bar stiffeners and spacing of $150 \mathrm{~mm}$; (c) typical elevation of column with 3 bar stiffeners and spacing of $100 \mathrm{~mm}$, (unit: $\mathrm{mm}$ )

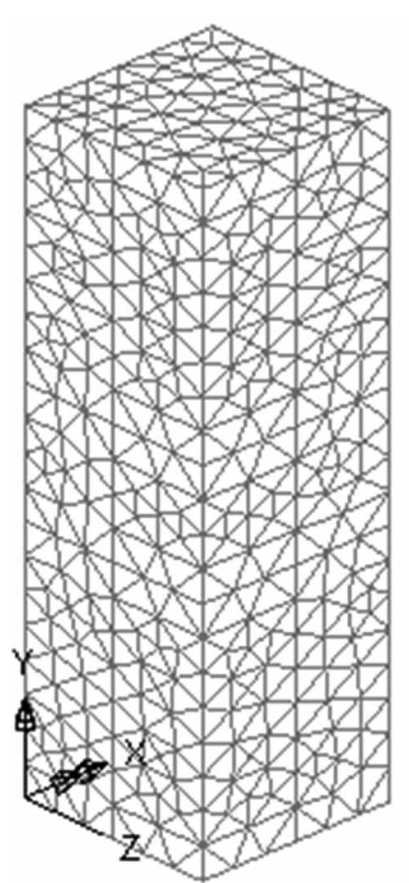

a

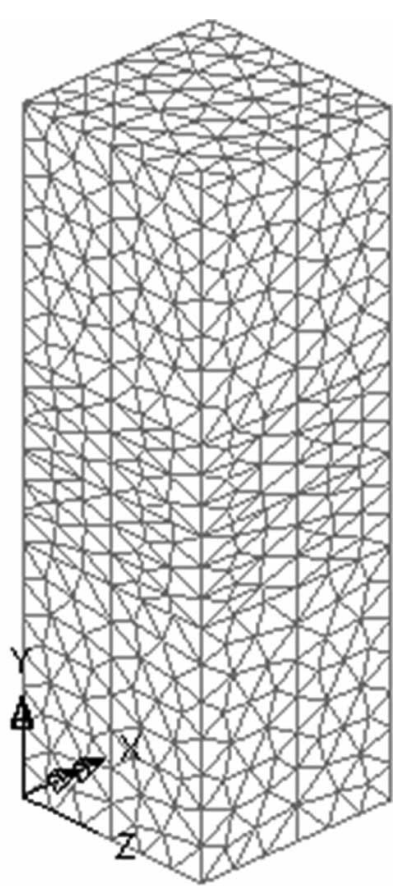

b
Fig. 8. Typical finite element meshes of the stiffened CFSC stub columns: (a) column with 2 bar stiffeners and spacing of $150 \mathrm{~mm}$; (b) column with 3 bar stiffeners and spacing of $100 \mathrm{~mm}$

stiffeners $(50,100$ and $150 \mathrm{~mm})$ are considered in the analyses in which two typical elevations are shown in Figure $7 \mathrm{~b}$ and c. Moreover, typical finite element meshes of the columns are illustrated in Figure 8.

\section{Results and discussion}

Features and obtained ultimate axial load capacities of the CFSC stub columns are listed in Table 1. The $C$ in the column labels represents the columns and the first four numbers following $C$ respectively designate the steel wall thickness $t(\mathrm{~mm})$, diameter of bar stiffener $D(\mathrm{~mm})$, steel wall yield stress $f_{y}(\mathrm{MPa})$ and concrete compressive strength $f_{c}(\mathrm{MPa})$. Also, the number before the parentheses is the number of bar stiffeners and the number in the parentheses presents the centre-to-centre spacing $(\mathrm{mm})$ between the bar stiffeners. Effects of different variables on the behaviour of the columns are also discussed in the following sections.

\subsection{Effect of number of bar stiffeners on ultimate axial load capacity}

To study the effect of number of bar stiffeners on the behaviour of the CFSC stub columns, the varied number of bar stiffeners (2, 3 and 4) (Fig. 7a) were considered in the analyses. Figure 9 shows these effects on the ultimate axial load capacity of the columns. 
Table 1. Features and obtained ultimate axial load capacities $\left(N_{u}\right)$ of the columns

\begin{tabular}{|c|c|c|c|c|c|c|}
\hline No. & Column label & Steel wall, $t(\mathrm{~mm})$ & Bar stiffener $D(\mathrm{~mm})$ & Steel wall, $f_{y}(\mathrm{MPa})$ & Concrete, $f_{c}(\mathrm{MPa})$ & $N_{u}(\mathrm{kN})$ \\
\hline 1 & C-2.5-10-234-50-4(50) & 2.5 & 10 & 234.3 & 50.1 & 3700 \\
\hline 2 & C-2.5-10-234-50-3(50) & 2.5 & 10 & 234.3 & 50.1 & 3606 \\
\hline 3 & C-2.5-10-234-50-2(50) & 2.5 & 10 & 234.3 & 50.1 & 3486 \\
\hline 4 & C-2.5-10-234-50-4(100) & 2.5 & 10 & 234.3 & 50.1 & 3611 \\
\hline 5 & C-2.5-10-234-50-3(100) & 2.5 & 10 & 234.3 & 50.1 & 3516 \\
\hline 6 & C-2.5-10-234-50-2(100) & 2.5 & 10 & 234.3 & 50.1 & 3410 \\
\hline 7 & C-2.5-10-234-50-4(150) & 2.5 & 10 & 234.3 & 50.1 & 3557 \\
\hline 8 & C-2.5-10-234-50-3(150) & 2.5 & 10 & 234.3 & 50.1 & 3456 \\
\hline 9 & C-2.5-10-234-50-2(150) & 2.5 & 10 & 234.3 & 50.1 & 3353 \\
\hline 10 & C-3-10-234-50-4(50) & 3 & 10 & 234.3 & 50.1 & 3856 \\
\hline 11 & C-2-10-234-50-4(50) & 2 & 10 & 234.3 & 50.1 & 3544 \\
\hline 12 & C-3-10-234-50-3(50) & 3 & 10 & 234.3 & 50.1 & 3741 \\
\hline 13 & C-2-10-234-50-3(50) & 2 & 10 & 234.3 & 50.1 & 3469 \\
\hline 14 & C-3-10-234-50-2(50) & 3 & 10 & 234.3 & 50.1 & 3635 \\
\hline 15 & C-2-10-234-50-2(50) & 2 & 10 & 234.3 & 50.1 & 3334 \\
\hline 16 & C-2.5-12-234-50-4(50) & 2.5 & 12 & 234.3 & 50.1 & 3735 \\
\hline 17 & C-2.5-8-234-50-4(50) & 2.5 & 8 & 234.3 & 50.1 & 3658 \\
\hline 18 & C-2.5-12-234-50-3(50) & 2.5 & 12 & 234.3 & 50.1 & 3648 \\
\hline 19 & C-2.5-8-234-50-3(50) & 2.5 & 8 & 234.3 & 50.1 & 3560 \\
\hline 20 & C-2.5-12-234-50-2(50) & 2.5 & 12 & 234.3 & 50.1 & 3504 \\
\hline 21 & C-2.5-8-234-50-2(50) & 2.5 & 8 & 234.3 & 50.1 & 3461 \\
\hline 22 & C-2.5-10-234-40-4(50) & 2.5 & 10 & 234.3 & 40 & 3093 \\
\hline 23 & C-2.5-10-234-30-4(50) & 2.5 & 10 & 234.3 & 30 & 2490 \\
\hline 24 & C-2.5-10-234-40-3(50) & 2.5 & 10 & 234.3 & 40 & 3010 \\
\hline 25 & C-2.5-10-234-30-3(50) & 2.5 & 10 & 234.3 & 30 & 2404 \\
\hline 26 & C-2.5-10-234-40-2(50) & 2.5 & 10 & 234.3 & 40 & 2915 \\
\hline 27 & C-2.5-10-234-30-2(50) & 2.5 & 10 & 234.3 & 30 & 2325 \\
\hline 28 & C-2.5-10-450-50-4(50) & 2.5 & 10 & 450 & 50.1 & 4322 \\
\hline 29 & C-2.5-10-350-50-4(50) & 2.5 & 10 & 350 & 50.1 & 4052 \\
\hline 30 & $C-2.5-10-450-50-3(50)$ & 2.5 & 10 & 450 & 50.1 & 4165 \\
\hline 31 & C-2.5-10-350-50-3(50) & 2.5 & 10 & 350 & 50.1 & 3925 \\
\hline 32 & C-2.5-10-450-50-2(50) & 2.5 & 10 & 450 & 50.1 & 4034 \\
\hline 33 & C-2.5-10-350-50-2(50) & 2.5 & 10 & 350 & 50.1 & 3819 \\
\hline
\end{tabular}

Also, Table 1 lists the corresponding ultimate axial load capacity values of the curves. According to the figure and table, the ultimate axial load capacity of the unstiffened CFSC stub column is improved by the use of the bar stiffeners. For instance, the use of four bar stiffeners (C-2.5-10-234-50-4(50)) increases the ultimate axial load capacity of the unstiffened column from 3325 to $3700 \mathrm{kN}$, an enhancement of $11.3 \%$. Also, increasing the number of bar stiffeners enhances the ultimate axial load capacity of the columns. For example, as the number of bar stiffeners is enhanced from 2 (C-2.5-10-234-50-2(150)) to 4 (C-2.5-10-234$50-4(150)$ ) for the same bar spacing of $150 \mathrm{~mm}$, the ultimate axial load capacity is increased from 3353 to $3557 \mathrm{kN}$, an improvement of $6.1 \%$.

\subsection{Effect of spacing of bar stiffeners on ultimate axial load capacity}

Three various bar spacing of 50, 100 and $150 \mathrm{~mm}$ were adopted in the analyses to examine the effect of spacing of bar stiffeners on the behaviour of the CFSC stub columns. This effect on the ultimate axial load capacity of the columns is illustrated in Figure 10. As can be seen from the figure and Table 1, the decrease of spacing of the bar stiffeners enhances the ultimate axial load capacity. As an example, the ultimate axial load capacity increases from 3456 (C2.5-10-234-50-3(150)) to $3606 \mathrm{kN}(\mathrm{C}-2.5-10-234-50-$ $3(50)$ ) if spacing of the bar stiffeners decreases from 150 to $50 \mathrm{~mm}$ with the same number of bar stiffeners, an enhancement of $4.3 \%$.

\subsection{Effect of steel wall thickness on ultimate axial load capacity}

The effect of steel wall thickness on the behaviour of the CFSC stub columns was evaluated by considering three different steel wall thicknesses of 2, 2.5 and $3 \mathrm{~mm}$ in the analyses. Figure 11 shows the results. In accordance with the figure and Table 1 , as the steel wall thickness enhances the ultimate axial load 

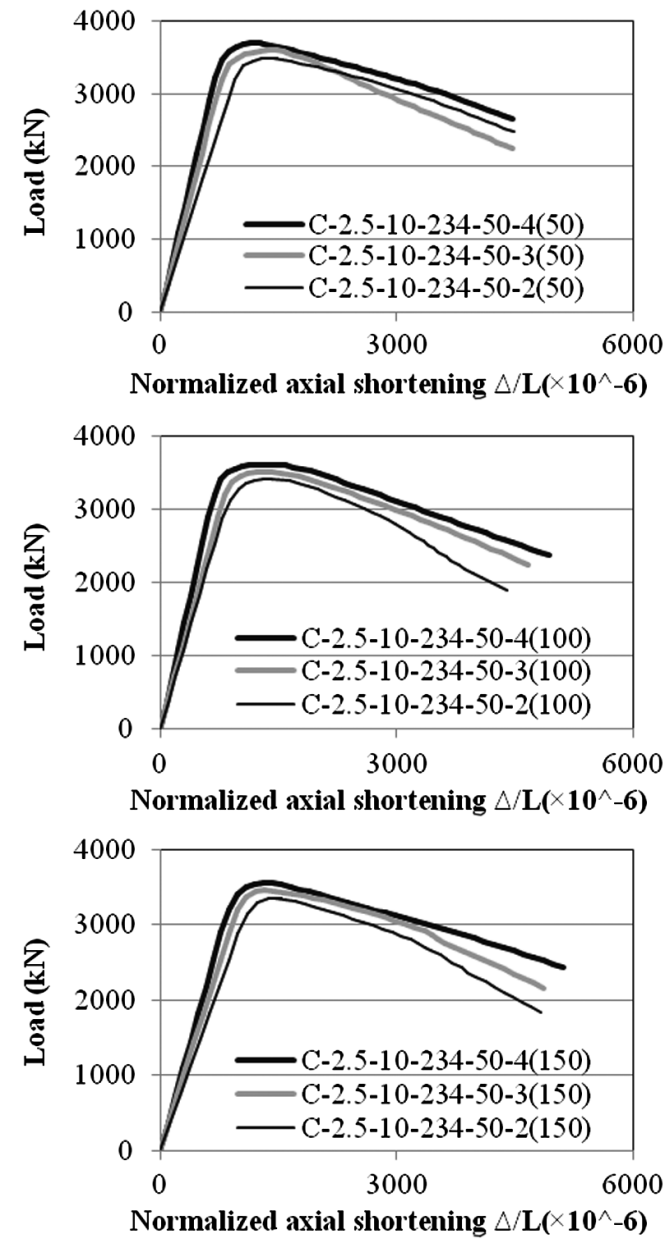

Fig. 9. Effects of number of bar stiffeners on ultimate axial load capacity

capacity increases. For instance, the increase of the steel wall thickness from 2 (C-2-10-234-50-4(50)) to $3 \mathrm{~mm}$ (C-3-10-234-50-4(50)) with the same number and spacing of the bar stiffeners improves the ultimate axial load capacity of the columns from 3544 to $3856 \mathrm{kN}$, an increase of $8.8 \%$.

\subsection{Effect of diameter of bar stiffeners on ultimate axial load capacity}

To investigate the effect of diameter of bar stiffeners on the ultimate axial load capacity of the CFSC stub columns, three various diameters of the bar stiffeners $(8,10$ and $12 \mathrm{~mm})$ were utilised in the analyses. The results are indicated in Figure 12. According to the figure and Table 1, higher ultimate axial load capacity can be obtained by larger diameter of the bar stiffeners. For example, as the diameter of the bar stiffeners increases from 8 (C-2.5-8-234-50-3(50)) to $12 \mathrm{~mm}$ (C2.5-12-234-50-3(50)) for the same number and spacing of the bar stiffeners, the ultimate axial load capacity enhances from 3560 to $3648 \mathrm{kN}$, an enhancement of $2.5 \%$ and not much appreciable.

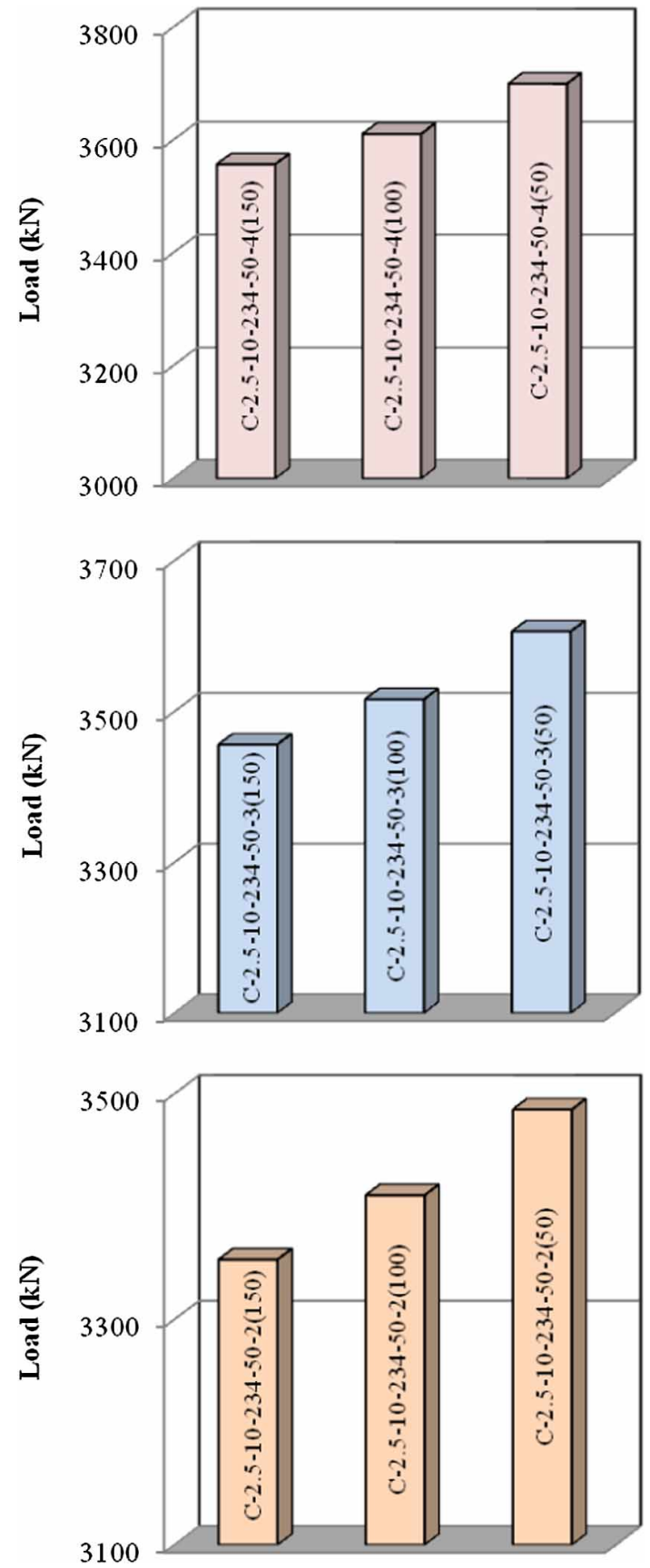

Fig. 10. Effects of spacing of bar stiffeners on ultimate axial load capacity

\subsection{Effects of number and spacing of bar stiffeners on ductility}

The ductility of the columns is assessed by the use of a ductility index (DI) as following (Lin, Tsai 2001):

$$
D I=\frac{\varepsilon_{85 \%}}{\varepsilon_{y}}
$$

in which $\varepsilon_{85 \%}$ is the nominal axial shortening $(\Delta / L)$ corresponding to the load which falls to its $85 \%$ of the ultimate axial load capacity and $\varepsilon_{y}$ is $\varepsilon_{75 \%} / 0.75$ where 

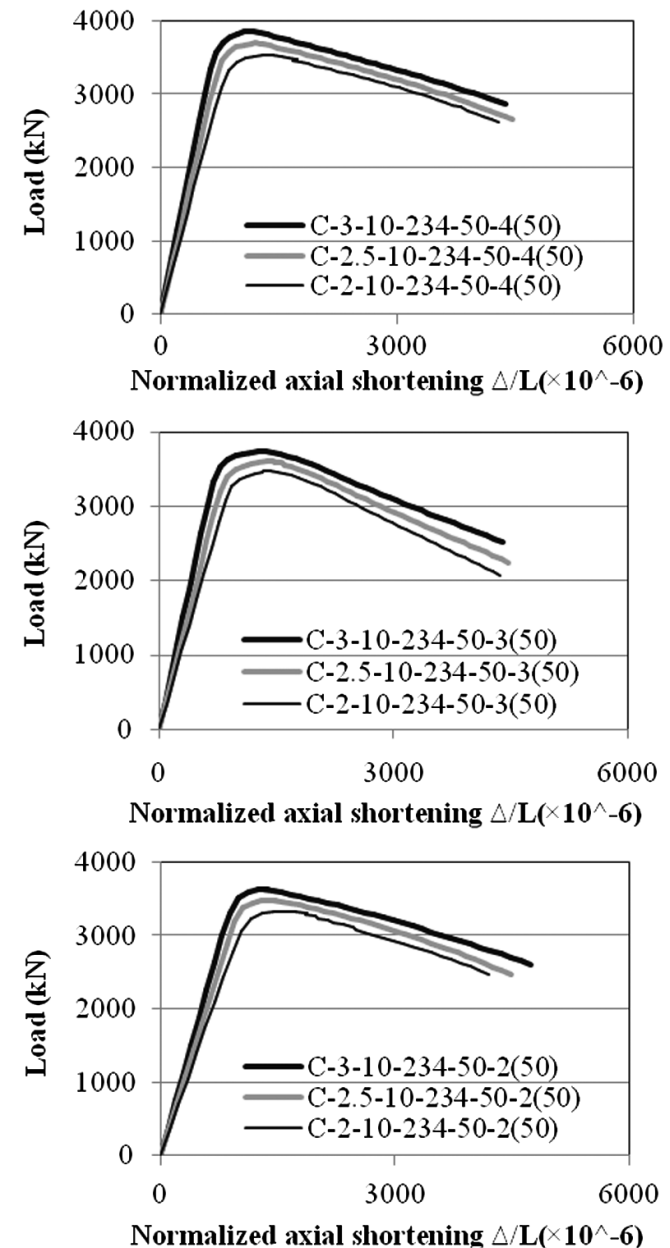

Fig. 11. Effect of steel wall thickness on ultimate axial load capacity

$\varepsilon_{75} \%$ is the nominal axial shortening corresponding to the load that obtains $75 \%$ of the ultimate axial load capacity. The values of $\varepsilon_{85} \%$ and $\varepsilon_{y}$ can be taken from Figure 9. Figure 13 illustrates effects of number and spacing of bar stiffeners on the ductility of the columns.

The increase of the number of bar stiffeners enhances the ductility of the columns (Fig. 13). For instance, the ductility of the columns is increased from 3.112 (C-2.5-10-234-50-2(50)) to 3.363 (C-2.5-10-234$50-4(50))$ by the enhancement of the number of bar stiffeners from 2 to 4 for the same bar stiffeners spacing of $50 \mathrm{~mm}$, an increase of $8.1 \%$.

In addition, the reduction of spacing of the bar stiffeners leads to increase of the ductility. As an example, if the bar stiffeners spacing is reduced from 150 (C-2.5-10-234-50-4(150)) to $50 \mathrm{~mm}$ (C-2.5-10-234$50-4(50)$ ), the ductility of the columns is enhanced from 3.150 to 3.363 , an improvement of $6.8 \%$.

\subsection{Effect of thickness of steel wall on ductility}

The ductility index, Eqn (12), is also used to study the effect of steel wall thickness on the ductility of the
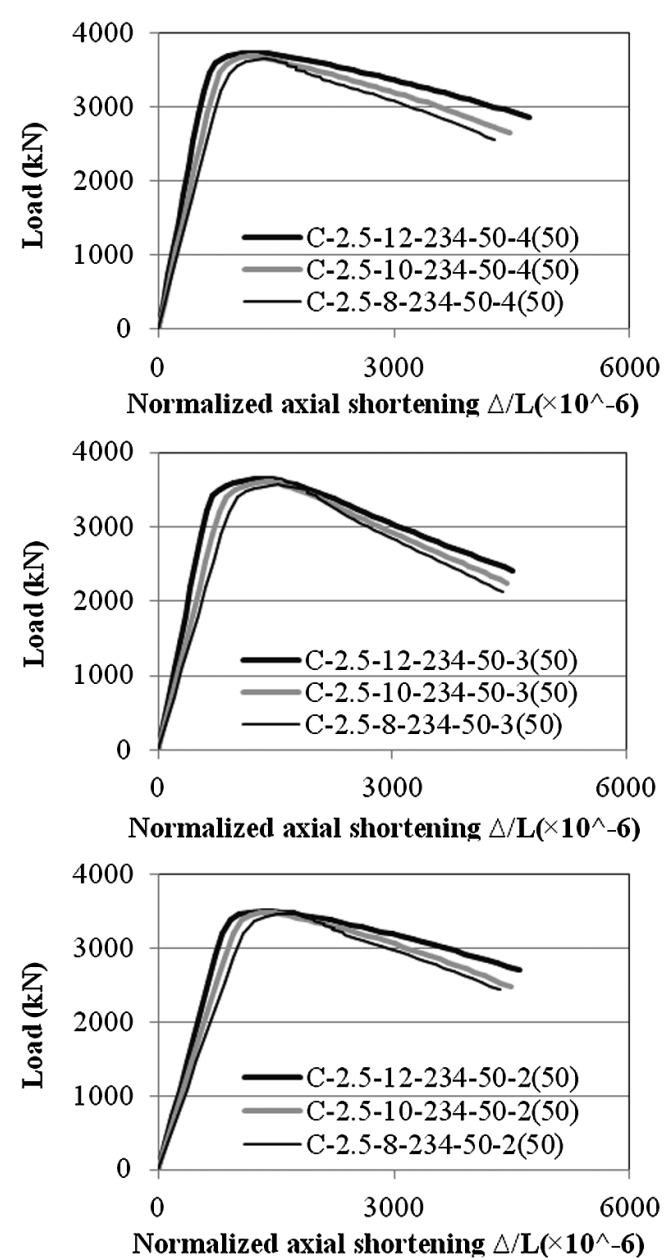

Fig. 12. Effect of diameter of bar stiffeners on ultimate axial load capacity

columns. This effect on the ductility of the columns is shown in Figure 14. The thicker steel wall results in the greater ductility (Fig. 14). For example, increasing the steel wall thickness from 2 (C-2-10-234-50-2(50)) to $3 \mathrm{~mm}$ (C-3-10-234-50-2(50)) improves the ductility from 2.984 to 3.245 , an improvement of $8.7 \%$.

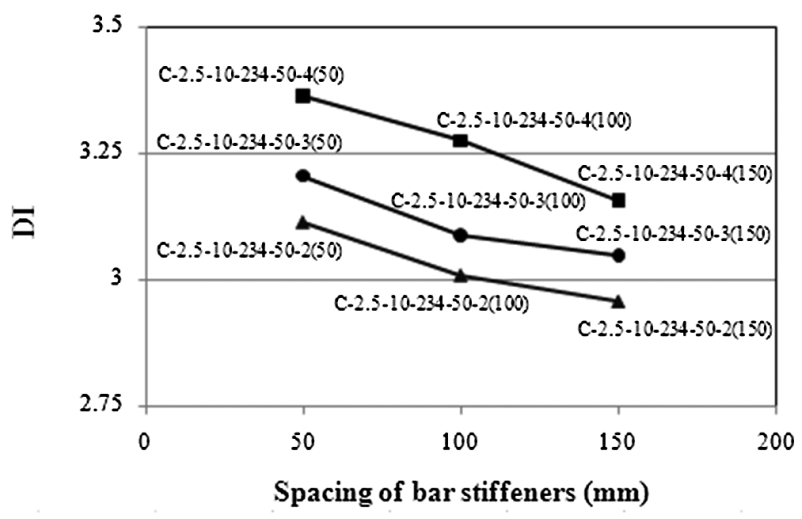

Fig. 13. Effects of number and spacing of bar stiffeners on ductility 


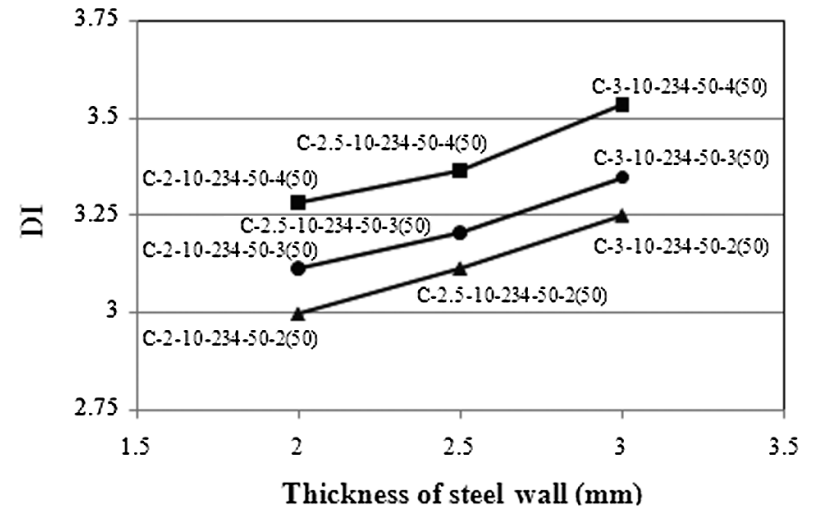

Fig. 14. Effect of steel wall thickness on ductility

\subsection{Effect of concrete compressive strength on ultimate axial load capacity}

Different concrete compressive strengths (30, 40 and $50.1 \mathrm{MPa}$ ) have been considered in the analyses to assess their effect on the ultimate axial load capacity of the columns (Fig. 15). It can be seen from the figure
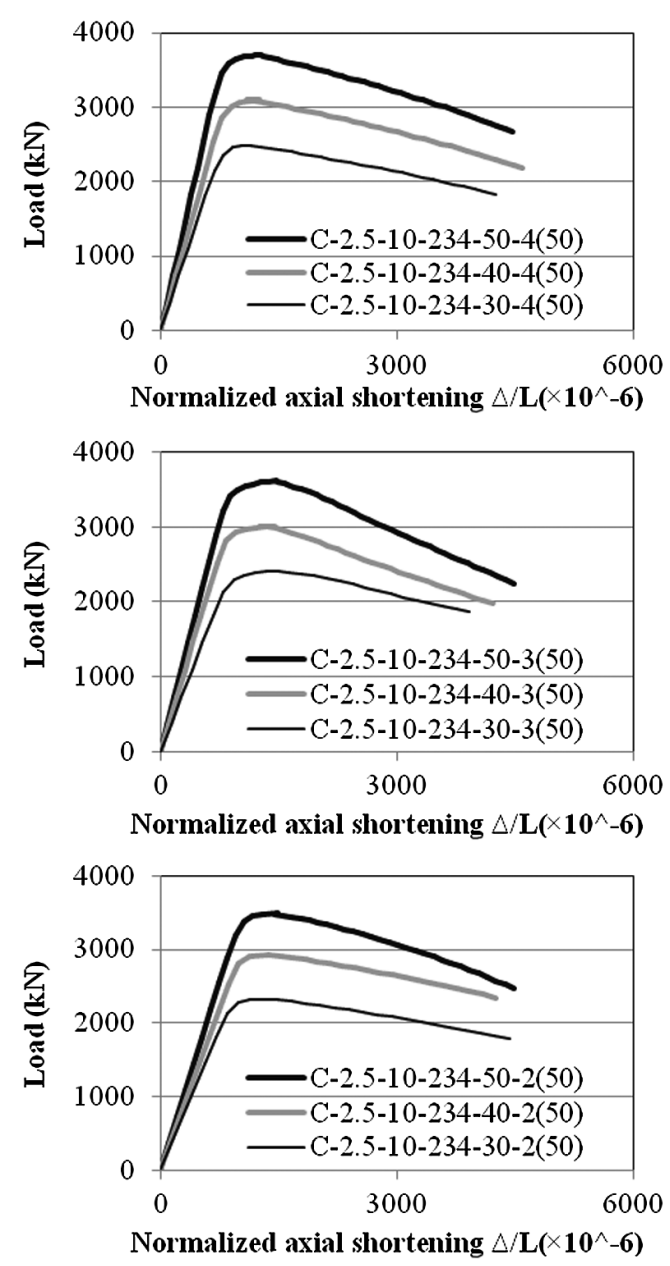

Fig. 15. Effect of concrete compressive strength on ultimate axial load capacity and Table 1 that the increase of the concrete compressive strength enhances the ultimate axial load capacity of the columns. As an example, the ultimate axial load capacity is increased from 2490 to $3700 \mathrm{kN}$ as the concrete compressive strength is enhanced from 30 (C-2.5-10-234-30-4(50)) to 50.1 MPa (C-2.5-10234-50-4(50)), an improvement of $48.6 \%$.

\subsection{Effect of steel yield stress on ultimate axial load capacity}

The effect of different steel yield stresses $(234.3,350$ and $450 \mathrm{MPa}$ ) on the ultimate axial load capacity of the columns is shown in Figure 16. As can be seen from the figure and Table 1, the higher steel yield stress leads to larger ultimate axial load capacity of the columns. For instance, the ultimate axial load capacity is increased from 3700 to $4322 \mathrm{kN}$ respectively for the steel yield stresses of 234.3 (C-2.5-10-234-50-4(50)) and $450 \mathrm{MPa}$ (C-2.5-10-450-50-4(50)), an enhancement of $16.8 \%$.
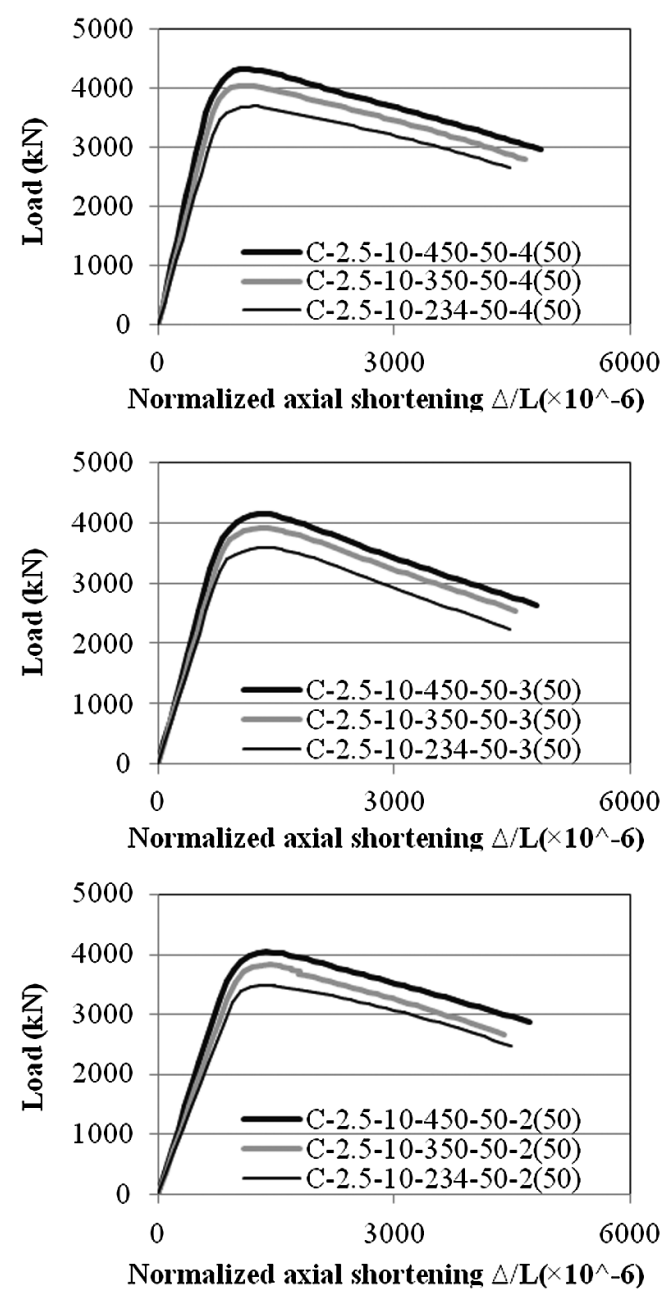

Fig. 16. Effect of steel yield stress on ultimate axial load capacity 


\subsection{Failure modes of stiffened CFSC stub columns}

Figures 17 and 18 show the typical failure modes of the columns in the cross section and elevation respectively. According to Figure 18, the failure modes of the columns were characterised as concrete crushing about their mid-height where the steel wall buckled locally. Also, the inward buckling of the steel wall was prevented by the in-filled concrete.

It can be also mentioned that the enhancement of the ultimate axial load capacity and ductility of the columns owing to the use of the bar stiffeners, increase of the number of bar stiffeners, decrease of spacing of the bar stiffeners, increase of the steel wall thickness, or enhancement of diameter of the bar stiffeners can be because of the increase of the confinement effect provided by the steel wall on the concrete core. As the confinement effect is enhanced the local buckling of the steel wall is delayed, which results in the improvement of the ultimate axial load capacity and ductility of the columns.

\subsection{Comparison of obtained ultimate axial load capacity with predictions}

The ultimate axial load capacity of a square or rectangular CFSC stub column can be predicted from Eqns (13), (14) and (15), respectively, based on Eurocode 4 (2004), Baig et al. (2006) and Bahrami et al. (2011b):

$$
N_{E C 4}=A_{c} f_{c}+A_{s} f_{y}
$$

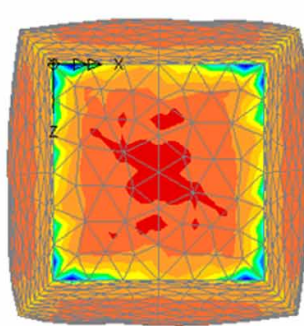

a

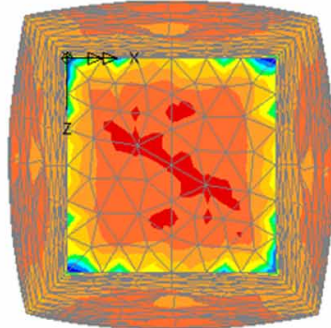

b

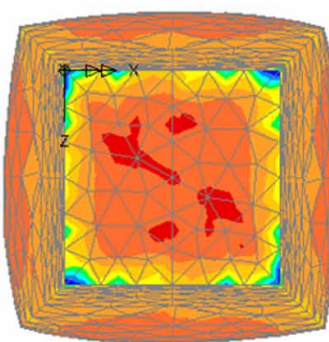

c

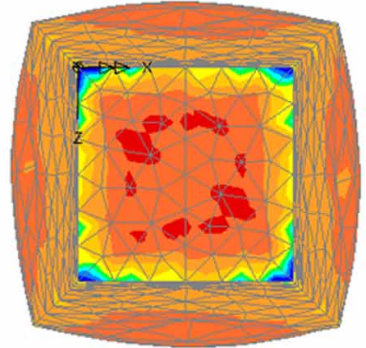

d

Fig. 17. Typical failure modes of the CFSC stub columns in the cross section: (a) column with 3 bar stiffeners and spacing of $50 \mathrm{~mm}$; (b) column with 4 bar stiffeners and spacing of $100 \mathrm{~mm}$; (c) column with 3 bar stiffeners and spacing of $150 \mathrm{~mm}$; (d) column with 4 bar stiffeners and spacing of $150 \mathrm{~mm}$

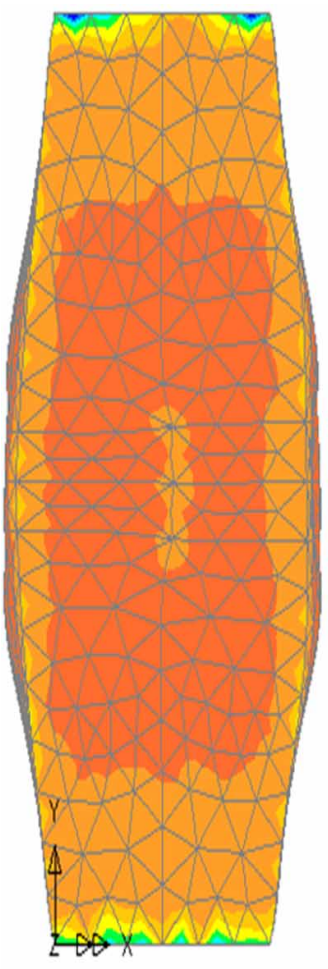

a

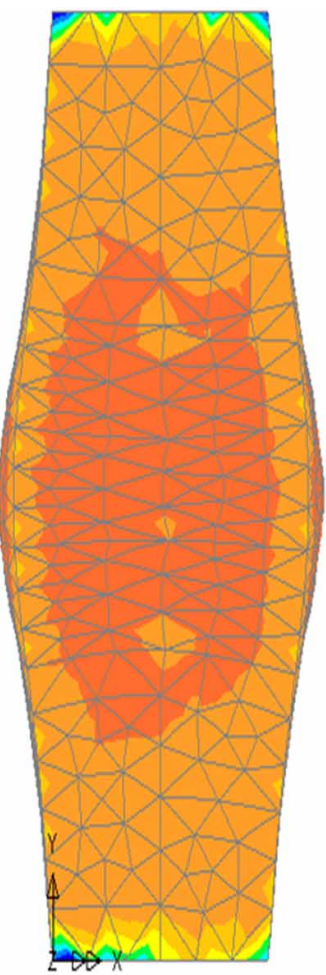

b

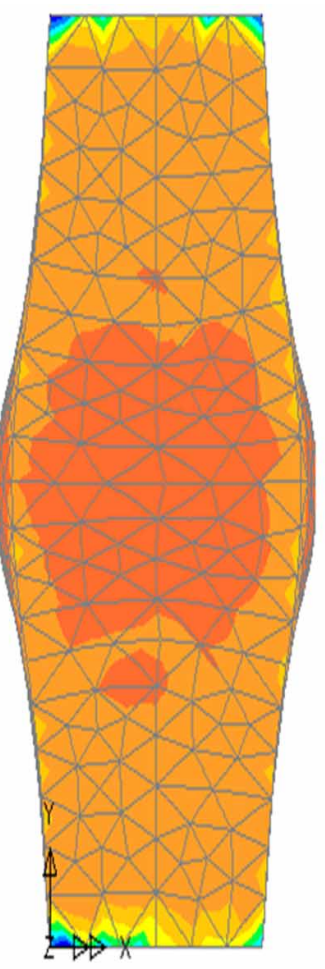

$\mathrm{c}$

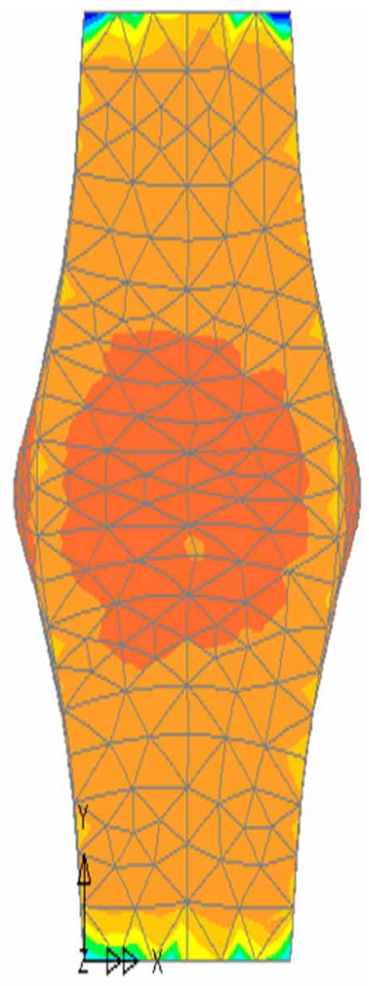

d

Fig. 18. Typical failure modes of the CFSC stub columns in the elevation: (a) column with 3 bar stiffeners and spacing of 50 $\mathrm{mm}$; (b) column with 4 bar stiffeners and spacing of $100 \mathrm{~mm}$; (c) column with 3 bar stiffeners and spacing of $150 \mathrm{~mm}$; (d) column with 4 bar stiffeners and spacing of $150 \mathrm{~mm}$ 


$$
\begin{aligned}
& N_{N}=1.10 A_{c} f_{c}+A_{s} f_{y} ; \\
& N_{B}=1.05 A_{c} f_{c}+A_{s} f_{y},
\end{aligned}
$$

in which $A_{c}$ and $A_{s}$ are areas of concrete and steel cross section respectively, and also $f_{c}$ and $f_{y}$ are compressive strength of the concrete core and yield stress of the steel wall, respectively. Table 2 summarises the predicted ultimate axial load capacities based on the mentioned equations and their comparisons with the values obtained from the non-linear analyses of the columns, $N_{u}$. Standard deviation and coefficient of variation are denoted as $\mathrm{SD}$ and $\mathrm{COV}$ in Table 2, respectively. A mean ratio $\left(N_{E C 4} / N_{u}\right)$ of 0.956 is achieved with a $\mathrm{COV}$ of 0.031 which reveals that Eurocode 4 (2004) underestimates the ultimate axial load capacity of the columns by $4.4 \%$. Also, a mean of 1.038 is obtained for $N_{N} / N_{u}$ with a COV of 0.034 which shows that Eqn (14) gives the ultimate axial load capacity of the columns by $3.8 \%$ higher than those from the non-linear analyses. Moreover, a mean ratio $\left(N_{B} / N_{u}\right)$ of 0.999 is achieved with a COV of 0.032 which uncovers that Eqn (15) underestimates the ultimate axial load capacity by only $0.1 \%$. Consequently, the proposed equation by Bahrami et al. (2011b), Eqn (15), can predict the ultimate axial load capacity of the columns with a very good accuracy.

\section{Conclusions}

CFSC stub columns with bar stiffeners have been investigated in this paper. The finite element software LUSAS was used to perform the non-linear analyses. Comparison of the modelling result with the existing experimental test result uncovered the accuracy of the proposed 3D finite element modelling. It was revealed that the proposed modelling can predict the behaviour of the columns with a reasonable accuracy. A special arrangement of bar stiffeners in the columns with various number, spacing and diameters of bar stiffeners

\begin{tabular}{|c|c|c|c|c|c|c|c|c|}
\hline No. & Column label & $N_{u}(\mathrm{kN})$ & $N_{E C 4}(\mathrm{kN})$ & $N_{E C 4} / N_{u}$ & $N_{N}(\mathrm{kN})$ & $N_{N} / N_{u}$ & $N_{B}(\mathrm{kN})$ & $N_{B} / N_{u}$ \\
\hline 1 & C-2.5-10-234-50-4(50) & 3700 & 3409 & 0.921 & 3728 & 1.008 & 3584 & 0.969 \\
\hline 2 & C-2.5-10-234-50-3(50) & 3606 & 3409 & 0.945 & 3728 & 1.034 & 3584 & 0.994 \\
\hline 3 & C-2.5-10-234-50-2(50) & 3486 & 3409 & 0.978 & 3728 & 1.069 & 3584 & 1.028 \\
\hline 4 & C-2.5-10-234-50-4(100) & 3611 & 3409 & 0.944 & 3728 & 1.032 & 3584 & 0.993 \\
\hline 5 & C-2.5-10-234-50-3(100) & 3516 & 3409 & 0.970 & 3728 & 1.060 & 3584 & 1.019 \\
\hline 6 & C-2.5-10-234-50-2(100) & 3410 & 3409 & 1.000 & 3728 & 1.093 & 3584 & 1.051 \\
\hline 7 & C-2.5-10-234-50-4(150) & 3557 & 3409 & 0.958 & 3728 & 1.048 & 3584 & 1.008 \\
\hline 8 & C-2.5-10-234-50-3(150) & 3456 & 3409 & 0.986 & 3728 & 1.079 & 3584 & 1.037 \\
\hline 9 & C-2.5-10-234-50-2(150) & 3353 & 3409 & 1.017 & 3728 & 1.112 & 3584 & 1.069 \\
\hline 10 & C-3-10-234-50-4(50) & 3856 & 3499 & 0.907 & 3782 & 0.981 & 3641 & 0.944 \\
\hline 11 & C-2-10-234-50-4(50) & 3544 & 3380 & 0.954 & 3672 & 1.036 & 3526 & 0.995 \\
\hline 12 & C-3-10-234-50-3(50) & 3741 & 3499 & 0.935 & 3782 & 1.011 & 3641 & 0.973 \\
\hline 13 & C-2-10-234-50-3(50) & 3469 & 3380 & 0.974 & 3672 & 1.059 & 3526 & 1.016 \\
\hline 14 & C-3-10-234-50-2(50) & 3635 & 3499 & 0.963 & 3782 & 1.040 & 3641 & 1.002 \\
\hline 15 & C-2-10-234-50-2(50) & 3334 & 3380 & 1.014 & 3672 & 1.102 & 3526 & 1.058 \\
\hline 16 & C-2.5-12-234-50-4(50) & 3735 & 3409 & 0.913 & 3728 & 0.998 & 3584 & 0.960 \\
\hline 17 & $C-2.5-8-234-50-4(50)$ & 3658 & 3409 & 0.932 & 3728 & 1.019 & 3584 & 0.980 \\
\hline 18 & C-2.5-12-234-50-3(50) & 3648 & 3409 & 0.934 & 3728 & 1.022 & 3584 & 0.982 \\
\hline 19 & C-2.5-8-234-50-3(50) & 3560 & 3409 & 0.958 & 3728 & 1.047 & 3584 & 1.007 \\
\hline 20 & C-2.5-12-234-50-2(50) & 3504 & 3409 & 0.973 & 3728 & 1.064 & 3584 & 1.023 \\
\hline 21 & C-2.5-8-234-50-2(50) & 3461 & 3409 & 0.985 & 3728 & 1.077 & 3584 & 1.036 \\
\hline 22 & C-2.5-10-234-40-4(50) & 3093 & 2860 & 0.925 & 3090 & 0.999 & 2975 & 0.962 \\
\hline 23 & C-2.5-10-234-30-4(50) & 2490 & 2285 & 0.918 & 2458 & 0.987 & 2371 & 0.952 \\
\hline 24 & C-2.5-10-234-40-3(50) & 3010 & 2860 & 0.950 & 3090 & 1.026 & 2975 & 0.988 \\
\hline 25 & C-2.5-10-234-30-3(50) & 2404 & 2285 & 0.950 & 2458 & 1.022 & 2371 & 0.986 \\
\hline 26 & C-2.5-10-234-40-2(50) & 2915 & 2860 & 0.981 & 3090 & 1.060 & 2975 & 1.020 \\
\hline 27 & C-2.5-10-234-30-2(50) & 2325 & 2285 & 0.983 & 2458 & 1.057 & 2371 & 1.020 \\
\hline 28 & C-2.5-10-450-50-4(50) & 4322 & 3957 & 0.916 & 4245 & 0.982 & 4101 & 0.949 \\
\hline 29 & C-2.5-10-350-50-4(50) & 4052 & 3717 & 0.917 & 4005 & 0.988 & 3861 & 0.953 \\
\hline 30 & C-2.5-10-450-50-3(50) & 4165 & 3957 & 0.950 & 4245 & 1.019 & 4101 & 0.985 \\
\hline 31 & C-2.5-10-350-50-3(50) & 3925 & 3717 & 0.947 & 4005 & 1.020 & 3861 & 0.984 \\
\hline 32 & C-2.5-10-450-50-2(50) & 4034 & 3957 & 0.981 & 4245 & 1.052 & 4101 & 1.017 \\
\hline \multirow[t]{4}{*}{33} & C-2.5-10-350-50-2(50) & 3819 & 3717 & 0.973 & 4005 & 1.049 & 3861 & 1.011 \\
\hline & Mean & & & 0.956 & & 1.038 & & 0.999 \\
\hline & $\mathrm{SD}$ & & & 0.029 & & 0.035 & & 0.032 \\
\hline & $\mathrm{COV}$ & & & 0.031 & & 0.034 & & 0.032 \\
\hline
\end{tabular}

Table 2. Comparison of obtained ultimate axial load capacity $\left(N_{u}\right)$ with $N_{E C 4}, N_{N}$ and $N_{B}$ 
were developed using the non-linear finite element method. Effects of different variables such as various number, spacing and diameters of the bar stiffeners, steel wall thicknesses, concrete compressive strengths, and steel yield stresses on the structural behaviour of the columns were investigated in this study. It was demonstrated that these variables are effective on the behaviour of the columns. The ultimate axial load capacity and ductility of the columns are improved by the use of the bar stiffeners. The enhancement of the number of bar stiffeners and/or steel wall thickness increases the ultimate axial load capacity and ductility of the columns. As the diameter of the bar stiffeners enhances the ultimate axial load capacity increases. The reduction of spacing of the bar stiffeners increases the ultimate axial load capacity and ductility. Also, the higher concrete compressive strength results in larger ultimate axial load capacity. Moreover, the increase of the steel yield stress enhances the ultimate axial load capacity. Meanwhile, the failure modes of the columns were dominated by concrete crushing about their midheight, where the local buckling of the steel wall was induced. The in-filled concrete prevented the steel wall from the buckling inward. In addition, the ultimate axial load capacities of the columns were predicted based on Eurocode 4 (2004) and the equations recommended by Baig et al. (2006) and Bahrami et al. (2011b), and also compared with those obtained values from the non-linear analyses. These comparisons showed that Eurocode 4 (2004) and equations of Baig et al. (2006) and Bahrami et al. (2011b), respectively, predicted the ultimate axial load capacities with $4.4 \%$ underestimation (a COV of 0.031 ), $3.8 \%$ overestimation (a COV of 0.034 ), and $0.1 \%$ underestimation (a COV of 0.032). Therefore, the proposed equation by Bahrami et al. (2011b) could predict the ultimate axial load capacities of the columns with a very good accuracy.

\section{References}

ACI 318-99. 1999. Building code requirements for structural concrete and commentary. Detroit, USA: American Concrete Institute. 465 p.

Bahrami, A.; Wan Badaruzzaman, W. H.; Osman, S. A. 2011a. Nonlinear analysis of concrete-filled steel composite columns subjected to axial loading, Structural Engineering and Mechanics 39(3): 383-398.

Bahrami, A.; Wan Badaruzzaman, W. H.; Osman, S. A. 2011b. Behaviour of stiffened concrete-filled steel composite (CFSC) stub columns, Unpublished.

Baig, M. N.; Jiansheng, F. A. N.; Jianguo, N. I. E. 2006. Strength of concrete filled steel tubular columns, Tsinghua Science and Technology 11(6): 657-666. http://dx.doi.org/10.1016/S1007-0214(06)70248-6

Dabaon, M.; El-Khoriby, S.; El-Boghdadi, M.; Hassanein, M. F. 2009. Confinement effect of stiffened and unstiffened concrete-filled stainless steel tubular stub columns, Journal of Constructional Steel Research 65(8-9): 1846-1854.

http://dx.doi.org/10.1016/j.jcsr.2009.04.012 de Oliveira, W. L. A.; De Nardin, S.; de Cresce El Debs, A. L. H.; El Debs, M. K. 2010. Evaluation of passive confinement in CFT columns, Journal of Constructional Steel Research 66(4): 487-495.

http://dx.doi.org/10.1016/j.jcsr.2009.11.004

Ellobody, E.; Young, B. 2006a. Design and behaviour of concrete-filled cold-formed stainless steel tube columns, Journal of Engineering Structures 28(5): 716728.

http://dx.doi.org/10.1016/j.engstruct.2005.09.023

Ellobody, E.; Young, B. 2006b. Nonlinear analysis of concrete-filled steel SHS and RHS columns, ThinWalled Structures 44(8): 919-930. http://dx.doi.org/10.1016/j.tws.2006.07.005

Ellobody, E.; Young, B.; Lam, D. 2006. Behaviour of normal and high strength concrete-filled compact steel tube circular stub columns, Journal of Constructional Steel Research 62(7): 706-715. http://dx.doi.org/10.1016/j.jcsr.2005.11.002

Eurocode 4. 2004. Design of composite steel and concrete structures. Part 1-1: general rules and rules for buildings. London: British Standards Institution.

Gao, L.; Sun, H.; Jin, F.; Fan, H. 2009. Load-carrying capacity of high-strength steel box-sections I: stub columns, Journal of Constructional Steel Research 65(4): 918-924.

http://dx.doi.org/10.1016/j.jcsr.2008.07.002

Gho, W.-M.; Liu, D. 2004. Flexural behaviour of highstrength rectangular concrete-filled steel hollow sections, Journal of Constructional Steel Research 60(11): 1681-1696.

http://dx.doi.org/10.1016/j.jcsr.2004.03.007

Giakoumelis, G.; Lam, D. 2004. Axial capacity of circular concrete-filled tube columns, Journal of Constructional Steel Research 60(7): 1049-1068.

http://dx.doi.org/10.1016/j.jcsr.2003.10.001

Goode, C. D.; Kuranovas, A.; Kvedaras, A. K. 2010. Buckling of slender composite concrete-filled steel columns, Journal of Civil Engineering and Management 16(2): 230-237. http://dx.doi.org/10.3846/jcem.2010.26

Guo, L.; Zhang, S.; Kim, W.-J.; Ranzi, G. 2007. Behavior of square hollow steel tubes and steel tubes filled with concrete, Thin-Walled Structures 45(12): 961-973. http://dx.doi.org/10.1016/j.tws.2007.07.009

Han, L.-H.; Liu, W.; Yang, Y.-F. 2008. Behavior of thin walled steel tube confined concrete stub columns subjected to axial local compression, Thin-Walled Structures 46(2): 155-164. http://dx.doi.org/10.1016/j.tws.2007.08.029

Hu, H.-T.; Huang, C.-S.; Chen, Z.-L. 2005. Finite element analysis of CFT columns subjected to an axial compressive force and bending moment in combination, Journal of Constructional Steel Research 61(12): 1692-1712. http://dx.doi.org/10.1016/j.jcsr.2005.05.002

Hu, H.-T.; Huang, C.-S.; Wu, M.-H.; Wu, Y.-M. 2003. Nonlinear analysis of axially loaded concrete-filled tube columns with confinement effect, Journal of Structural Engineering ASCE 129(10): 1322-1329. http://dx.doi.org/10.1061/(ASCE)0733-9445(2003) 129:10(1322) 
Hu, H.-T.; Schnobrich, W. C. 1989. Constitutive modeling of concrete by using nonassociated plasticity, Journal of Materials in Civil Engineering ASCE 1(4): 199-216. http://dx.doi.org/10.1061/(ASCE)0899-1561(1989)1:4 (199)

Kuranovas, A.; Goode, D.; Kvedaras, A. K.; Zhong, S. 2009. Load-bearing capacity of concrete-filled steel columns, Journal of Civil Engineering and Management 15(1): 21-33. http://dx.doi.org/10.3846/1392-3730.2009.15.21-33

Kuranovas, A.; Kvedaras, A. K. 2007. Behaviour of hollow concrete-filled steel tubular composite elements, Journal of Civil Engineering and Management 13(2): 131-141.

Lakshmi, B.; Shanmugam, N. E. 2002. Nonlinear analysis of in-filled steel-concrete composite columns, Journal of Structural Engineering ASCE 128(7): 922-933. http://dx.doi.org/10.1061/(ASCE)0733-9445(2002) 128:7(922)

Lin, M. L.; Tsai, K. C. 2001. Behaviour of double-skinned composite steel tubular columns subjected to combined axial and flexural loads, in Proc. of the First International Conference on the Steel \& Composite Structures, 2001, Pusan, Korea, 1145-1152.

Liu, D. 2005. Tests on high-strength rectangular concretefilled steel hollow section stub columns, Journal of Constructional Steel Research 61(7): 902-911. http://dx.doi.org/10.1016/j.jcsr.2005.01.001

LUSAS User's Manual, Version 14. 2006. Surrey, UK: Finite Element Analysis Ltd.

Mander, J. B.; Priestley, M. J. N.; Park, R. 1988. Theoretical stress-strain model for confined concrete, Journal of Structural Engineering ASCE 114(8): 1804-1826. http://dx.doi.org/10.1061/(ASCE)0733-9445(1988) 114:8(1804)

Mursi, M.; Uy, B. 2003. Strength of concrete filled steel box columns incorporating interaction buckling, Journal of Structural Engineering ASCE 129(5): 626-639. http://dx.doi.org/10.1061/(ASCE)0733-9445(2003) 129:5(626)

Petrus, C.; Hamid, H. A.; Ibrahim, A.; Parke, G. 2010. Experimental behaviour of concrete filled thin walled steel tubes with tab stiffeners, Journal of Constructional Steel Research 66(7): 915-922.

http://dx.doi.org/10.1016/j.jcsr.2010.02.006

Richart, F. E.; Brandzaeg, A.; Brown, R. L. 1928. A study of the failure of concrete under combined compressive stresses, Bull. 185. Champaign, IL, USA: University of Illinois Engineering Experimental Station. 104 p.

Saenz, L. P. 1964. Discussion of 'Equation for the stressstrain curve of concrete' by Desayi, P.; Krishnan, S, Journal of the American Concrete Institute 61(9): 12291235.

Shakir-Khalil, H.; Mouli, M. 1990. Further tests on concrete-filled rectangular hollow-section columns, The Structural Engineer 68(20): 405-413.

Tao, Z.; Han, L.-H.; Wang, Z.-B. 2005. Experimental behaviour of stiffened concrete-filled thin-walled hollow steel structural (HSS) stub columns, Journal of Constructional Steel Research 61(7): 962-983. http://dx.doi.org/10.1016/j.jcsr.2004.12.003

Tao, Z.; Han, L.-H.; Wang, D.-Y. 2008. Strength and ductility of stiffened thin-walled hollow steel structural stub columns filled with concrete, Thin-Walled Structures 46(10): 1113-1128. http://dx.doi.org/10.1016/j.tws.2008.01.007

Uy, B. 1998. Ductility, strength and stability of concretefilled fabricated steel box columns for tall buildings, The Structural Design of Tall Buildings 7(2): 113-133. http://dx.doi.org/10.1002/(SICI)1099-1794(199806) 7:2\%3C113::AID-TAL94\%3E3.0.CO;2-I

Uy, B.; Tao, Z.; Han, L.-H. 2011. Behaviour of short and slender concrete-filled stainless steel tubular columns, Journal of Constructional Steel Research 67(3): 360-378. http://dx.doi.org/10.1016/j.jcsr.2010.10.004

Yang, Y.-F.; Han, L.-H. 2011. Behaviour of concrete filled steel tubular (CFST) stub columns under eccentric partial compression, Thin-Walled Structures 49(2): 379-395. http://dx.doi.org/10.1016/j.tws.2010.09.024

\begin{abstract}
Alireza BAHRAMI. PhD student in the Department of Civil and Structural Engineering, Universiti Kebangsaan Malaysia (UKM), Bangi, Selangor, Malaysia since 2009 to date. BE in Civil Engineering from Bushehr Islamic Azad University in 1998. MSc in Civil and Structural Engineering with an excellent grade from Universiti Kebangsaan Malaysia (UKM) in 2009. Fourteen years of industrial experience in Civil Engineering. A lecturer at some universities in Iran. Research interests: steel-concrete composite structural elements and their behaviour and also engineering software for structural elements analysis.
\end{abstract}

Wan Hamidon WAN BADARUZZAMAN. Professor in the Department of Civil and Structural Engineering, Universiti Kebangsaan Malaysia (UKM), Bangi, Selangor, Malaysia. PhD in Structural Engineering from the University of Wales, Cardiff, UK in 1994. Twenty-six years of vast teaching, training, research, publication, administration, accreditation and consultancy experiences. On secondment, was the Chief Executive Officer of the UKM Perunding Kejuruteraan \& Arkitek Sdn. Bhd., a university professional consultancy company. Research interests: steel-concrete composite structural elements, light weight, cold-formed composite structures and their behaviour.

Siti Aminah OSMAN. Dr, Senior lecturer in the Department of Civil and Structural Engineering, Universiti Kebangsaan Malaysia (UKM), Bangi, Selangor, Malaysia. A member of Board of Engineers Malaysia (BEM). Graduated from Universiti Teknologi Malaysia in 1992 with BE (Hons), MSc in Structural Engineering from University of Bradford, UK in 1995 and $\mathrm{PhD}$ in Civil and Structural Engineering from Universiti Kebangsaan Malaysia (UKM) in 2006. After undergraduate studies, started teaching as a lecturer at Universiti Kebangsaan Malaysia (UKM). Research interests: structural engineering, wind engineering and industrial building system (IBS) construction. 